\title{
Sustav za planiranje i implementaciju projektnih zadataka u nastavi informatike
}

\author{
Sara Vrsaljko \\ Ekonomsko-birotehnička škola Split \\ Vukovarska 37, Split \\ sara.vrsaljko@skole.hr
}

\author{
Jozo Pivac \\ Udruga za robotiku „Inovatic" \\ Ruđera Boškovića 33, Split \\ jozo.pivac@udruga-inovatic.hr
}

\author{
Vladimir Pleština \\ Prirodoslovno-matematički fakultet \\ Sveučilište u Splitu \\ Ruđera Boškovića 33, Split \\ vladimir.plestina@pmfst.hr
}

\section{Sažetak}

Nastava i oblik poučavanja orijentiran na projekte i rješavanje projektnih zadataka predstavlja odmak od klasične nastave i samim time učenicima je drugačija i zanimljivija. U ovom radu je iznesen prijedlog jednostavnog sustava za planiranje nastave informatike orijentirane rješavanju projektnih zadataka, kao prijedlog učiteljima i nastavnicima za pripremanje učenika za složeniju, projektno zasnovanu nastavu. Takav sustav predviđa planiranje, definiranje cilja, ishoda, uvodno testiranje, realizaciju, provjerljivost ishoda te analizu zadovoljstva. Cilj je ovakvog pristupa da se učenicima kroz zanimljivu temu (miniprojekt) približi problematika iz nastavnog kurikuluma te da se, na temelju povratne informacije od učenika, ustanovi njihova motiviranost za složenije strategije učenja i poučavanja, kao što je projektna nastava.

Ključne riječi: Micro:bit, programiranje, projektna nastava, projektni zadatak

\section{Uvod}

Nastava usmjerena projektima i projektnim zadacima pruža svojevrsni odmak od klasične nastave, potiče kod učenika suradničko učenje te pruža bolje mogućnosti samoostvarenja pojedinca u procesu učenja (dos Santos i sur., 2018; Pearlman i Thomas, 2000). U takvom pristupu svaki učenik prema svojim sposobnostima daje svoj prilog za uspješnu provedbu. Kako bi učenici sudjelovali u projektnoj nastavi moraju biti dovoljno kompetentni za postupanje s metodama i radnim tehnikama. Nastavnik je u ovom obliku nastave zadužen za davanje povratnih informacija učenicima. Osim toga, nastavnik mora motivirati učenika i pomoći im da prevladaju probleme i poteškoće pri realizaciji parcijalnih zadatka i rješavanju problema. Kako bi se projekt uspješno izveo, potrebna je gruba struktura za planiranje 
projekta koja služi za planiranje pojedinačnih faza (Mirković, 2015). Projekt u nastavi možemo definirati kao svaki učenički pothvat koji se može okarakterizirati kao cjelovit i zaokružen i čiji se ishodi i ciljevi mogu definirati. Osim toga, mora se ostvariti u određenom vremenskom intervalu i za uspješno ostvarivanje potreban je usklađen rad određene skupine učenika, ukoliko više učenika radi na jednom projektu (Čižmešija, 2006). Ono što je prednost kod poučavanja orijentiranog na realizaciju projekata je što razvija kod učenika određenu odgovornost i sposobnost, konstruktivnost, kritičnost te da ih potiče na kreativnost i inovativnost (Brankica, 2014). U većini projekata učenici bi trebali dobiti osjećaj i za važnost timskog rada te naučiti cijeniti doprinos svojih kolega. Osim toga, učenici bi trebali uočiti beneficije surađivanja. Razvijanje timskog i grupnog rada za učenike su jako važni, jer su za većinu poslova potrebne vještine komunikacije i suradnje. lako je projektna nastava jedan od didaktičkih pristupa poučavanju nastavnih sadržaja te je, kao takav, značajan za razvoj učenika u mnogo različitih aspekata, razmišljanja nastavnika su različita i podijeljena (Jurčić, 2010). Neki smatraju da je najveći problem u provođenju projektnog oblika rada upravo vrijeme i velika količina nastavnih sadržaja koji se trebaju obraditi tijekom nastavne godine. Drugi dio nastavnika smatra da nastavni sadržaji nisu toliko problematični, koliko su problematična motivacija, znanje i sposobnost koji su uvjeti da bi se mogla organizirati i voditi tako zahtjevna vrsta nastave (Šuliček, 2011). Općenito gledajući, projektna nastava predstavlja veliki izazov učiteljima (Pearlman i Thomas, 2000; Curto i Moreno, 2016). Neki od mogućih izazova na koji nailaze učitelji pri planiranju projekata je njihova složenost, što može rezultirati trajanjem projekta duže nego što je planirano, osjećajem nereda u razredu, nedovoljnim praćenjem učenika tijekom procesa širenja informacija, nedovoljnim ili prečestim uplitanjem nastavnika u učenički samostalni rad (Mubin i sur., 2013).

Unatoč nedostatcima i problemima $u$ izvođenju projekte nastave, istraživanja su pokazala da učenici u velikoj mjeri profitiraju od ovakvog oblika poučavanja (Elkin i sur., 2014).
Prednosti su, kao što je prije dijelom navedeno, povećavanje aktivnosti za učenje, učeničke motivacije, a posebice kod onih učenika kojima je nastava dosadna ili se tijekom nastave ponašaju nezainteresirano (Visković, 2016). Neka istraživanja pokazuju da faktori, kao što su dodatna motivacija koja može biti uvjetovana projektnim zadacima, utječu na poboljšano učenje u programiranju (Zainal i sur., 2012). Povezivanje programiranja sa učeničkim različitim interesima daje odmak u brzini i efikasnosti obrade nastavnih sadržaja što primjerice klasično poučavanje programiranja ne pruža dovoljno učenicima motivacije (Forte i Guzdial, 2005; Uludag, Karakus, Turner, 2011). Kad se sagledaju sve prednosti dobivene provedbom projektne nastave i problemi u izvedbi, može se zaključiti da se nije jednostavno pripremiti za ovakvo izvođenje nastave, ali da se isplati, ako će motivirati učenike $i$ navesti ih na razumijevanje gradiva i poboljšanje raznih vještina.

Kao pomoć i motivacijski alat za projektno učenje, u nastavi je moguće primijeniti parcijalne projektne zadatke. Naime, za razliku od projektne nastave, kao cjelovite nastavne strategije, projektni zadatci predstavljaju izoliranu aktivnost, koja se može relativno jednostavno primijeniti $u$ tradicionalnim okruženjima učenja i poučavanja, kakvo je uglavnom još uvijek prisutno u Hrvatskoj. $\mathrm{S}$ obzirom da projektna nastava zahtjeva visoku motiviranost učenika za takav rad, te određena znanja i vještine potrebne za razradu ideja $\mathrm{i}$ realizaciju projekta, ovakvi zadatci mogu činiti stanoviti uvod u projektnu nastavu i dati vrijednu povratnu informaciju učitelju o osobinama, mogućnostima i željama učenika.

$\mathrm{U}$ tom smislu, u ovom radu se predlaže jednostavni sustav planiranja i implementacije projektnih zadataka (mini projekata) u nastavi informatike, koji može doprinijeti motiviranju učenika za složenije projektne aktivnosti i osposobiti ih za suradnički projektni rad, a učiteljima i nastavnicima naviknutima na tradicionalnu nastavu olakšati buduće planiranje $\mathrm{i}$ pripremanje složenijih nastavnih pristupa i strategija kao što su problemska i projektna nastava. 


\section{Sustav za planiranje projektnih zadataka u okviru nastavnih sadržaja}

U ovom poglavlju opisan je teoretski primjer predloženog jednostavnog sustava za planiranje i strukturiranje projektnih zadataka (mini-projekta) u nastavi (Slika 1.).

Prije nego nastavnik krene $u$ realizaciju projektnih zadataka trebao bi biti svjestan predznanja i mogućnosti učenika o kojima ovisi uspješnost rješavanja predviđenih projektnih zadataka. Kako bi dobio povratne informacije o tome, poželjno je sastaviti ulazni test $s$ definiranim ishodima na temelju kojih će moći dalje planirati odabir projektnih zadataka ovisno o rezultatima. Nastavnik potom treba analizirati dobivene rezultate uvodnog testiranja i poseban naglasak staviti na ishode koji u uvodnom testiranju nisu zadovoljeni i pomoću kojih će odrediti daljnji tijek realizacije projektnih zadataka.

Za realizaciju projektnih zadataka nastavnik treba, uzimajući u obzir ishode koje učenici trebaju ostvariti, osmisliti set predvježbi ili predavanja koji će prethoditi realizaciji samog projektnog zadatka. Set vježbi/predavanja bi trebao učenike pripremiti da mogu samostalno pristupiti projektnom zadatku i riješiti ga uspješno. Cijeli ciklus prije projektnog zadatka može se održati u više uzastopnih dana ili se može razvući na nekoliko tjedana. Projektni zadatak bi trebao slijediti nakon višesatnog učenja i usvajanja novih koncepata i pojmova, a tijekom realizacije zadatka učenik bi trebao moći primijeniti prethodno naučene koncepte. Ovisno o vrsti i načinu pripreme projektnih zadataka, učenici zadatku pristupaju samostalno, u paru, grupi ili kroz timski rad. Nastavnik je tijekom realizacije projektnog zadatka uz učenike i po potrebi ih navodi na dobar smjer rješavanja. Rezultat projektnog zadatka, kao finalni produkt, bi trebao činiti određenu smislenu cjelinu koju učenici kasnije mogu upotrijebiti ili prezentirati i temeljem kojega će biti vidljiva ostvarenost ishoda učenja. Zadovoljene ishode možemo vidjeti kroz zainteresiranost učenika, pokazane vještine i znanje pri izradi i nakon realizacije projekta, te iskazanu samostalnost $u$ radu.

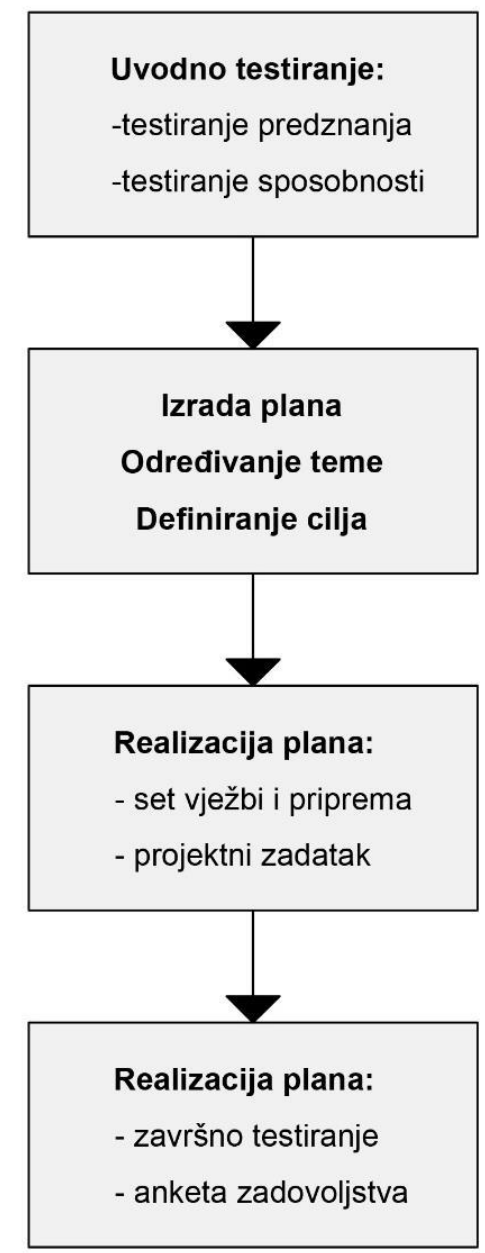

Slika 1. Shematski prikaz prijedloga planiranja projektnog zadatka u okviru nastavnih sadržaja

Nakon što učenici završe s izradom projektnog zadatka potrebno je i egzaktno utvrditi jesu li, u kojoj mjeri i na kojoj razini učenici usvojili prezentirano i u projektu korišteno gradivo. Za to je potreban izlazni evaluacijski instrument izlazni test. Izlazni test će dati uvid u zadovoljene ili nezadovoljene ishode koji su definirani tijekom seta vježbi/predavanja i projektnog zadatka, a na temelju usporedbe $s$ uvodnim testiranjem. Uz 
izlazni test važno je dobiti i povratnu informaciju o zadovoljstvu i motivaciji učenika kroz ostvaren mini-projekt, a to je moguće putem ankete zadovoljstva. Tako nastavnik, kao izlazne povratne informacije, ima dvije dimenzije rezultata za svakog učenika, njegovo usvojeno znanje te njegova motivacija, zadovoljstvo $s$ naučenim gradivom i realizacijom vlastitog projektnog zadatka.

\section{Prijedlog implementacije projektnih zadataka u okviru nastavnih sadržaja informatike}

Implementacija predloženog sustava za planiranje projektnih zadataka u okviru nastavnih sadržaja je osmišljena za učenike sedmog razreda osnovne škole.

\subsection{Uvodno testiranje}

Uvodno testiranje će pokazati koliko je predznanje tj. kakve su mogućnosti svakog učenika. lako bi za neki drugi nastavni predmet mogli postaviti samo točno konkretna pitanja $i$ zadatke da bi vidjeli je li učenik prethodno usvojio gradivo koje mu je potrebno za izradu projekta, informatika je u tom slučaju specifičan predmet. Prvo što svaki nastavnik iz informatike mora uzeti u obzir jest da informatika nije bila obvezni predmet do 2018/2019. školske godine. Druga stvar o kojoj nastavnik mora voditi računa jest da je trenutno postala obvezan predmet samo za učenike petih i šestih razreda. Može se dogoditi da neki učenik koji nije pohađao informatiku u petom razredu, upiše informatiku $u$ šestom razredu $\mathrm{i}$ on $\mathrm{u}$ tom slučaju nije imao priliku usvojiti gradivo i u zaostatku je u odnosu na svoje kolege koji su se već susreli s nekim pojmovima i gradivom. Ta se razlika poprilično osjeti kad je riječ o programiranju. Upravo iz tog razloga se $u$ svakoj nastavnoj godini treba posvetiti neko vrijeme za ponavljanje $\mathrm{i}$ ponovno usvajanje ključnih i osnovnih pojmova u programiranju. Zbog prethodno navedenih razloga i neredovitosti u pohađanju informatike, a i same mogućnosti da su učenici zaboravili gradivo iz programiranja, napravljeno je uvodno testiranje koje ne provjerava učenikovo znanje iz programiranja već učeničku logiku razmišljanja koja mu je potrebna da bi savladao nadolazeće gradivo. Ulazni test je osmišljen kao set zadataka za logičko razmišljanje $s$ definiranim ishodima koje se može povezati s usvajanjem gradiva iz programiranja. Zadaci su osmišljeni po uzoru na zadatke koji su po tipu slični zadacima za testiranje učenika iz Centra izvrsnosti iz informatike Splitsko-dalmatinske županije i tipovima zadataka koji se koriste na Informatičkom natjecanju u logičkom razmišljanju „Dabar".

\subsection{Planiranje realizacije mini-projekta i definiranje cilja}

Projektni zadatak bi trebao potaknuti učenike na više samostalnog rada i suradnje s kolegama. Osim toga, učenici bi kao izlaz trebali dobiti nekakav konačni rezultat koji će moći negdje prezentirati ili iskoristiti. Naravno, kroz cijeli proces realizacije projektnog zadatka trebali bi i steći određena znanja i sposobnosti. Ako obuhvatimo sve prethodno napisano, možemo definirati cilj projektnog zadatka:

- Usvojiti osnovne pojmove i koncepte u programiranju realizacijom mini-projekta korištenjem Micro:bit mikroupravljača.

Kao što sam prijedlog sustava za planiranje projektne nastave kaže, nakon uvodnog testiranja na redu je i planiranje izvođenja same nastave. Zbog prije spomenute pretpostavke da se neki od učenika nisu prije susreli $s$ gradivom iz programiranja i iz istog razloga zbog kojeg zadaci za ulazno testiranje ne provjeravaju prethodno usvojeno znanje, učenicima se pristupa kao da prije nisu radili ništa iz programiranja. Znači da se s njima usvajaju pojmovi i rade zadaci kao da prvi put programiraju, iako su se neki od njih već susreli s određenim pojmovima i gradivom. Cijeli ciklus je osmišljen tako da se prvo krene s kratkim zadacima. Kroz kratke zadatke će učenici savladati nove pojmove i koncepte koji su razbijeni na više školskih sati. S obzirom na vremensko ograničenje od šest školskih sati koji su raspoređeni u blok 
satu u trajanju od tri tjedna, raspored predloženog sustava bi trebao izgledati:

- Učenici rješavaju ulazni test (1 školski sat).

- Preko više kratkih zadataka učenici usvajaju potrebna znanja i vještine koje im trebaju za izradu projektnog zadatka (3 školska sata).

- Učenici izrađuju projektni zadatak (1 školski sat).

- Učenici rješavaju završni test $\mathrm{i}$ ispunjavaju anketu zadovoljstva (1 školski sat).

Kao što se može vidjeti iz rasporeda, za izradu projektnog zadatka rezerviran je jedan školski sat. Zbog kratkog vremena za izradu projektnog zadatka, opsega gradiva koji učenici moraju savladati i alata Micro:bita zaključeno je da bi idealni projektni zadatak bila jednostavna, interaktivna računalna igra implementirana $u$ Micro:bit simulator. Za tu igru odabrana je stara igra iz dalmatinske zagore, šijavica. Šijavica je igra u kojoj može sudjelovati dva ili više igrača. Svaki od igrača zamisli dva broja. Prvi broj je broj koji igrač pokazuje na ruci i koji je iz intervala od jedan do pet, a drugi broj je broj koji igrač izgovori i koji je njegova pretpostavka za protivnikov odabir broja. Izgovoren broj za svakog igrača je zbroj njegovog broja prstiju s ruke i pretpostavljenog broja prstiju $s$ ruke protivnika. Nastavni sat $s$ projektom je osmišljen da se učenici prvo upoznaju s igrom šijavica i nakon toga dobiju upute kako je implementirati u Micro:bit simulator. $\mathrm{Na}$ kraju školskog sata, nakon što učenici implementiraju igru u projekt, trebaju pomoću Micro:bita ponovno zaigrati sa svojim suigračima. Pobjednik je igrač čiji je izgovoren broj zbroj njegovog i protivnikovog broja pokazanih prstiju. Preko ove igre, a i na samom početku projektnog sata kroz pitanja, učenici ponove većinu koncepata u programiranju koje su kroz cijeli ciklus vježbi trebali savladati i tako ih usvoje.

\subsection{Završno testiranje i anketiranje}

Nakon što učenici završe s izradom projektnog zadatka i odigraju pokoji krug sa svojim suigračem, poslije projektnog sata počinje i zadnji nastavni sat ciklusa tj. završno testiranje koje je sačinjeno od sedam zadataka. Za završni test učenici imaju riješiti manji broj zadataka zato što učenicima u 45 minuta nastavnog sata treba ostaviti vremenskog prostora i za anketiranje. Zadaci završnog testiranja koncipirani su kao zadaci na papiru u kojima učenici trebaju doći do ispravnog zaključka i među svim ponuđenim odgovorima zaokružiti ispravan. Zadnjih deset minuta završnog nastavnog sata rezervirano je za anketiranje kojemu učenici mogu pristupiti nakon što riješe završni test. Pomoću ankete se dobiva povratna informacija učenika koja govori o njihovoj motivaciji i zadovoljstvu $s$ pojedinim aspektima cijelog ciklusa.

Tablica 1. Ishodi učenja po ciklusima projektnog zadatka

\begin{tabular}{|c|c|c|c|c|}
\hline 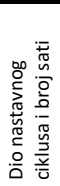 & $\begin{array}{l}\text { Ishodi } \\
\text { vezani za } \\
\text { korelaciju s } \\
\text { matematički } \\
\text { m } \\
\text { operacijama }\end{array}$ & $\begin{array}{l}\text { Ishodi } \\
\text { vezani za } \\
\text { algoritam } \\
\text { ponavljanja }\end{array}$ & $\begin{array}{l}\text { Ishodi } \\
\text { vezani za } \\
\text { korištenje } \\
\text { varijabli }\end{array}$ & $\begin{array}{l}\text { Ishodi } \\
\text { vezani za } \\
\text { algoritam } \\
\text { grananja }\end{array}$ \\
\hline 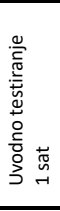 & $\begin{array}{l}\text { Primijeniti } \\
\text { svoje znanje } \\
\text { iz } \\
\text { matematike } \\
\text { za rješavanje } \\
\text { zadatka. }\end{array}$ & $\begin{array}{l}\text { Identificirati } \\
\text { uzorak } \\
\text { ponavljanja. }\end{array}$ & $\begin{array}{l}\text { Upotrijebiti } \\
\text { broj u } \\
\text { zadatku kao } \\
\text { da je } \\
\text { spremljen u } \\
\text { varijablu. }\end{array}$ & $\begin{array}{l}\text { Primijetiti } \\
\text { sve uvjete } \\
\text { napisane u } \\
\text { zadatku i za } \\
\text { svaki uvjet } \\
\text { ispitati sve } \\
\text { elemente } \\
\text { niza. } \\
\end{array}$ \\
\hline 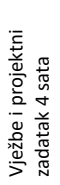 & $\begin{array}{l}\text { Razlikovati } \\
\text { uvećavanje } \\
\text { brojača od } \\
\text { matematičk } \\
\text { og izraza. }\end{array}$ & $\begin{array}{l}\text { Prepoznati } \\
\text { program u } \\
\text { kojem treba } \\
\text { koristiti } \\
\text { petlju. }\end{array}$ & $\begin{array}{l}\text { Samostalno } \\
\text { kreirati } \\
\text { varijable i } \\
\text { postaviti ih } \\
\text { na neku } \\
\text { vrijednost ili } \\
\text { slučajni broj. }\end{array}$ & $\begin{array}{l}\text { Razlikovati } \\
\text { naredbe } \\
\text { grananja po } \\
\text { broju } \\
\text { postavljenih } \\
\text { uvjeta. }\end{array}$ \\
\hline 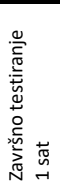 & $\begin{array}{l}\text { Primijeniti } \\
\text { varijablu u } \\
\text { ulozi } \\
\text { brojača. }\end{array}$ & $\begin{array}{l}\text { Prepoznati } \\
\text { algoritam } \\
\text { ponavljanja i } \\
\text { njegovu } \\
\text { ulogu u } \\
\text { izvršavanju } \\
\text { programa. }\end{array}$ & $\begin{array}{l}\text { Primijeniti } \\
\text { varijablu u } \\
\text { ulozi brojača }\end{array}$ & $\begin{array}{l}\text { Primijeniti } \\
\text { poznavanje } \\
\text { algoritma } \\
\text { grananja u } \\
\text { izvršavanju } \\
\text { programa. }\end{array}$ \\
\hline
\end{tabular}

Nakon odrađenog projektnog zadatka učenici bi se trebali osjećati ispunjeno i motivirano za daljnji rad na projektima. Ovakva nastava bi in ujedno trebala motivirati za osmišljavanje $i$ razradu vlastitih ideja za nadogradnju postojećeg projekta, te nadahnuti za kreiranje vlastitih. Ako je riješenost završnog testiranja zadovoljavajuća, znači da su ishodi definirani kroz cijeli ciklus ispunjeni. U sljedećoj tablici (tablica 1.) se nalaze 
ishodi podijeljeni po grupama kojima pripadaju $\mathrm{i}$ podijeljeni na dijelove. $U$ posljednjem potpoglavlju je napisana analiza ishoda i njihovog međusobnog odnosa s obzirom na grupu ishoda kojoj pripadaju i s obzirom na dio ciklusa za koji su postavljeni.

\section{Primjena projektnog zadatka}

U ovom poglavlju se nalaze zadaci iz uvodnog $\mathrm{i}$ završnog testiranja, te kratki opis svake vježbe. Kako bi se što jasnije ukazalo na svrhovitost sustava, odnosno, predviđeni učinak na učenike, primjer je realiziran kao nastavnikovo akcijsko istraživanje u stvarnim školskim uvjetima. Na taj su se način željeli izbjeći neprirodni uvjeti te posebna pripremljenost i stanje učenika tijekom provedbe istraživanja.

\subsection{Zadaci iz uvodnog testiranje}

$\mathrm{Na}$ sljedećoj slici (Slika 2.) nalaze se prvih pet zadataka iz uvodnog testiranja. Svih pet zadataka imaju više ponuđenih rješenja od kojih je jedno ispravno. Svih pet zadataka su osmišljeni po uzoru na zadatke iz testiranja za Centar izvrsnosti iz informatike.

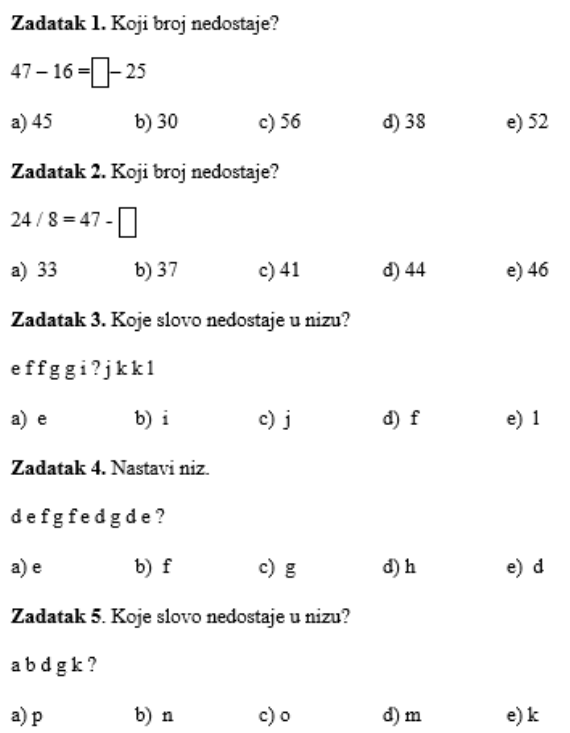

Slika 2. Prvih pet zadataka iz uvodnog testiranja
Šesti zadatak iz uvodnog testiranja je nešto drugačiji jer učenici trebaju nastaviti niz sličica. Ovakav tip zadatka čest je na testovima inteligencije (Slika 3.).

Zadatak 6. Nastavi niz
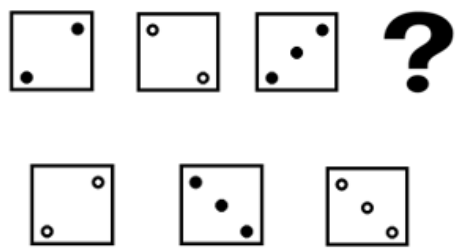

b)
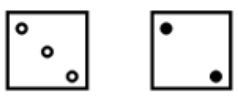

a)

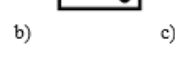

c) 1

Slika 3. Šesti zadatak uvodnog testiranja

Sedmi zadatak je posljednji kreiran po uzoru na zadatke iz Centra za izvrsnost (Slika 4.).

Osmi zadatak, uz preostale zadatke, osmišljen je po uzoru na zadatke iz Dabra (Slika 5., Slika 6., Slika 7., Slika 8., Slika 9.).

Zadatak 7. Ivan je stigao u zabavni park $i$ kupio je karte za najzanimljiviju atrakciju, ali umjesto natpisa s nazivom atrakcije dobio je kartu s napisanim brojem 2 . Ušao je u park i sad traži natpis s brojem kojeg je dobio da bi mogao pristupiti atrakciji za koju je kartu kupio. Na slici je prikazana mapa puta do atrakcije. Koja je Ivanova željena atrakcija?

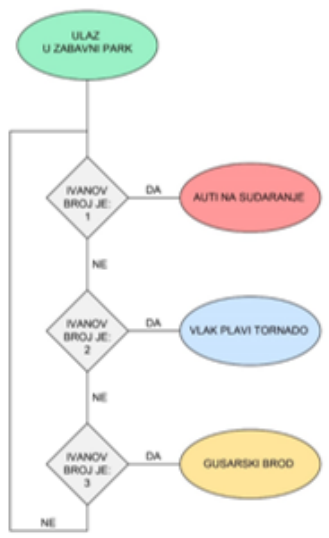

a) Auti na sudaranje

b) Vlak plavi tomado

c) Gusarski brod 
Zadatak 8. Ante i Marko su braća i dijele mnogo zajedničkih igračaka. Između ostalog i vlakić s jako puno vagona. Marko je mlađi brat i u slobodno vrijeme voli zadirkivati svog starijeg brata. Nakon što je Ante složio vlak i vagone, otišao se malo odmoriti, a kad se vratio, primijetio je da mu nekoliko vagona u nizu nedostaje i da su sad razdvojeni u dva niza. Marko mu je rekao da treba pogoditi točan broj vagona koji mu nedostaju ako želi da mu ih vrati nazad. Ante se ne sjeća koliko je vagona ukupno imao, ali se sjeća redoslijeda boja po kojem je slagao vagone. Pomozi Anti da odredi koliko mu vagona nedostaje.

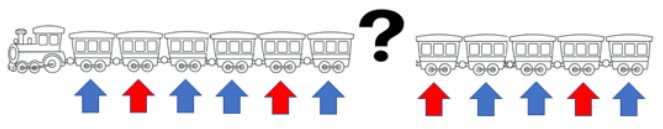

Marko je Anti ponudio tri moguća odgovora. Zaokruži ispravno rješenje.

a) 6 vagona mu nedostaje

b) 7 vagona mu nedostaje

c) 8 vagona mu nedostaje

Slika 5. Zadatak s vlakovima iz uvodnog testiranja

Zadatak 9. Maja je pozvana na tematsku rođendansku zabavu na koju je trebala ponijeti svoju novu najdražu lutku. Ta lutka je trenutačno popularna među djevojčicama. Majina mama je znala da će sve ostale djevojčice ponijeti istu lutku na zabavu te ju je označila na poseban način tako da se razlikuje od ostalih. Iako je Maji naglasila detalje s kojim ce razlikovati svoju lutku od ostalih, druge su mame napravile slične oznake i na kraju rođendanske zabave Maja je zbunjena i ne može prepoznati svoju lutku. Pomozi Maji da pronađe svoju lutku ako znaš što je mama Maji rekla:

- Majina lutka na haljini ima točno 10 ruža

- Majina lutka nosi lančić

- Majina lutka ima narukvicu na desnoj ruci

- Majina lutka ima jednu ružu na gornjem djelu haljine prišivenu na traku

Slika 6. Tekst zadatka s lutkama iz uvodnog testiranja
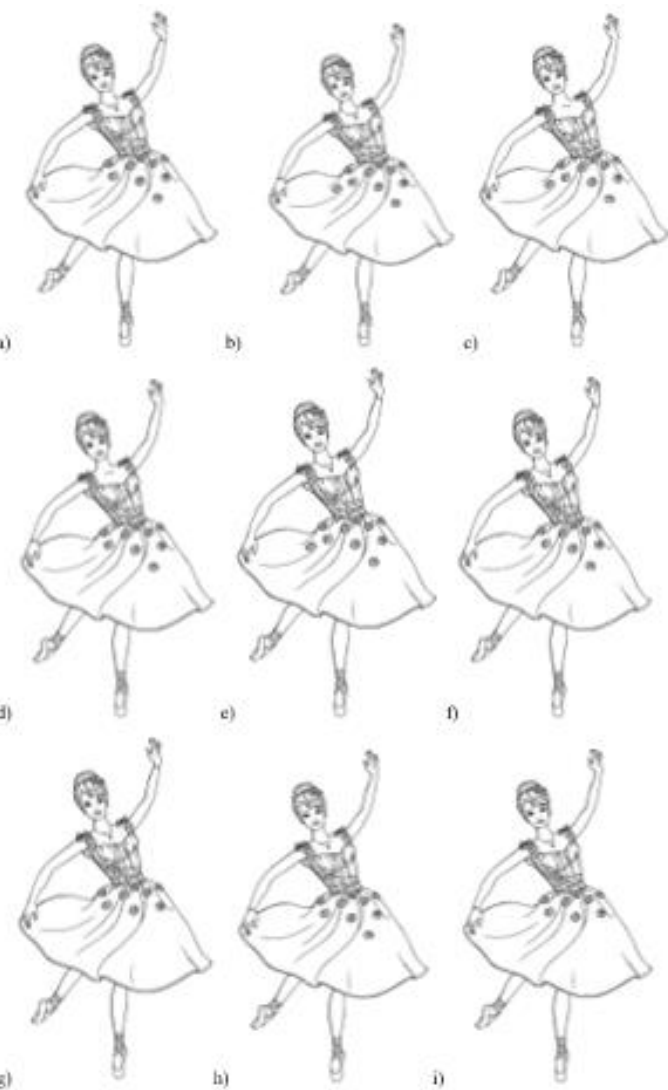

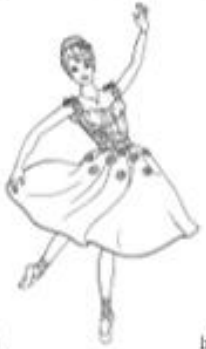

Slika 7. Zadatak s lutkama 
Zadatak 10. Ana i Ivan jedva čekaju Božićno vrijeme jer in mama tada da zadatak da zajedno ukrase Božićno drvce. Ove godine im je mama kupila posebne lampice na kojima piše Božic. Nakon s̆to su ukrasili cijelo druce i lampice Božic postavili pri vrhu drvca, pročitali su upute i skvatili da svako slovo sačinjeno od lampica pojedinačno periodički mijenja boju. Redoslijed mijenjanja boje je gljedeći nakon zlatne (žute) uvijek ide crvena, nakon crvene zelena, a nakon zelene ponowno je na redu zlatna.

Svaka boja traje odredeno vrijeme

- Zlatma boja: 3 minute

- Crvena boja: 2 minute

- Zelena boja: 1 minutu

Osim toga, ako 3 uzastopna slova istovremeno zasvijetle u zlatmu boju, arednje slovo ce odmal prijeći u crvenu. Lampice su namjeàtene tako da pri uključivanju u struju zasvijetle sa sljedećim rasporedom boja:

\section{BOŽC}

Kako ce izgledati natpis tijekom 5. minute nakon paljenja lampica?

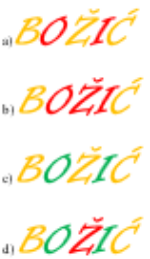

Slika 8. Zadatak s Božićem

Zadatak 11. David je za rodendan dobio robota na daljingko upravijanje. Robot ima senzor koji mu omogucáava da se zaustavi prije nego se zabije u zid ili nekakvu drugu prepreku. David je napravio labirint od kartona i krenuo u istrǎ̌ivanje. Daljingki upravljač kojim upravlija robotom ima ove mogućnosti

- Na gumb naprijed robot će ići naprijed do prve prepreke ili do pritisnutog gumba stop.

- Na gumb stop robot će se zaustaviti.

- Na gumb lijevo robot će se rotirati lijevo.

- Na gumb desno robot će se rotirati desno.

Daxida zanima koliko će puta do dolaska na cilj trebati stianuti neki od botuna na daljinskom upravljacu, ako gumb stop ne mora stignuti na samom cilju jer je postavio ogracu kartona i robot će se sam zaustaviti kad prepozna prepreku.

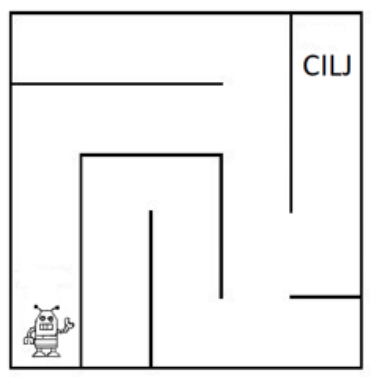

a) 9 puta će pritisnuti na daljingki upravljač

b) 10 puta će pritisnuti na daljinski upravljač

c) 11 puta će pritianuti na daljingki upravijač

d) 12 puta će pritisnuti na daljinski upraviljač

Slika 9. Zadatak s robotom i labirintom

\subsection{Vježbe i projektni zadatak}

Tijekom tri vježbe koje su prethodile realizaciji mini-projekta obrađeni su osnovni koncepti programiranja. Veći dio tih koncepata primijenjen je i tijekom realizacije projektnog zadatka. Prva vježba slijedila je nakon uvodnog testiranja. Pošto je skupina učenika koja je sudjelovala u nastavnom ciklusu već prije programirala, prvi sat je obrađeno dosta osnovnih pojmova kroz jednostavne zadatke. Obrađeni pojmovi na prvoj vježbi bili su: Programiranje, program, naredba, algoritam slijeda, algoritam ponavljanja, događaj, istovremene radnje $u$ programiranju, varijabla $i$ slučajni broj. Za tjedan dana slijedile su još dvije vježbe raspoređene u blok-sat. Tijekom blok-sata ponovljeni su prethodno usvojeni programi uz dodavanje novih: Grananje, uvjet, petlja, brojač, varijabla i algoritam ponavljanja. Na prvom od dva blok-sata stavljen je naglasak na algoritam grananja, a na drugom na algoritam ponavljanja. Tjedan dana nakon toga učenici su prvi sat $u$ program implementirali projektnu igru „Šijavica“. Programiranju igrice je prethodilo objašnjavanje pravila igre, te definiranje parova. Parovi su odmah nakon objašnjavanja pravila mogli zaigrati nekoliko kratkih partija igre, a i nakon same implementacije isprobati kako igrica funkcionira na Micro:bitu

\subsection{Završno testiranje i anketa zadovoljstva}

Zadnji sat bio je predviđen za kombinaciju testiranja i anketiranja učenika. Završno testiranje se sastojalo od 7 zadataka na papiru gdje su učenici trebali prepoznati koje je od ponuđenih rješenja točan odgovor na postavljeno pitanje. $\mathrm{Na}$ sljedećim slikama se nalaze pitanja iz završnog testa s ponuđenim odgovorima (Slika 10., Slika 11.,Slika 12., Slika 13., Slika 14.). 
Zadatak 1. Zaokruži koliko će se puta na zaslonu s led diodama prikazati slovo $\mathrm{A}$.

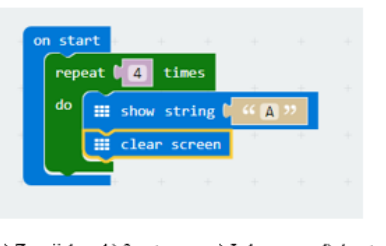

Zadatak 2. Koji je najveći broj koji se može prikazati na led diodama na kraju ovog programa?

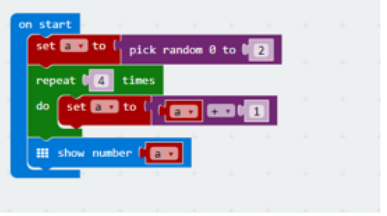

$\begin{array}{llll}\text { a) } 3 & \text { b) } 4 & \text { c) } 6 & \text { d) } 5\end{array}$

Slika 10. Prva dva zadatka iz završnog testiranja

Zadatak 3. Koliko puta će se u ovom programu prikazati ikona sretnog smješka na led diodama?

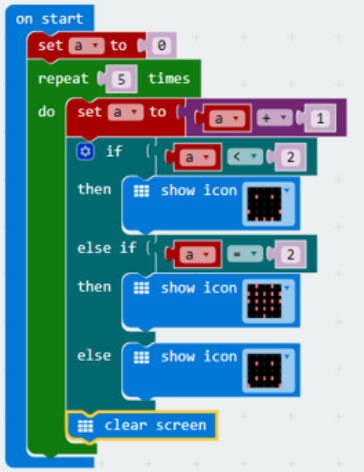

a) 2 puta

b) 3 puta

c) 1 put

d) Niti jednom

Slika 11. Treći zadatak iz završnog testiranja
Zadatak 4. Koje će se slovo prikazati na led diodama tijekom drugog izvođenja petlje?

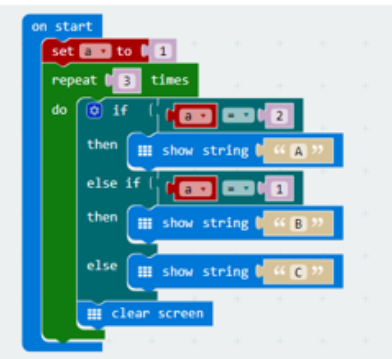

a) $\mathrm{C}$

b) A

c) $\mathrm{B}$

Zadatak 5. Koja će vrijednost varijable $a$ biti na kraju izvođenja programa?

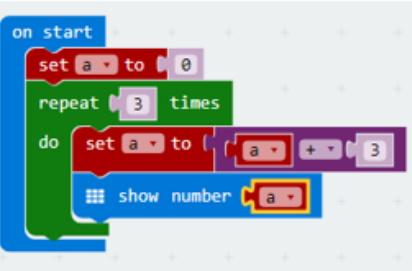

a) 6

b) 3

c) 9

d) 10

Slika 12. Četvrti i peti zadatak iz završnog testiranja

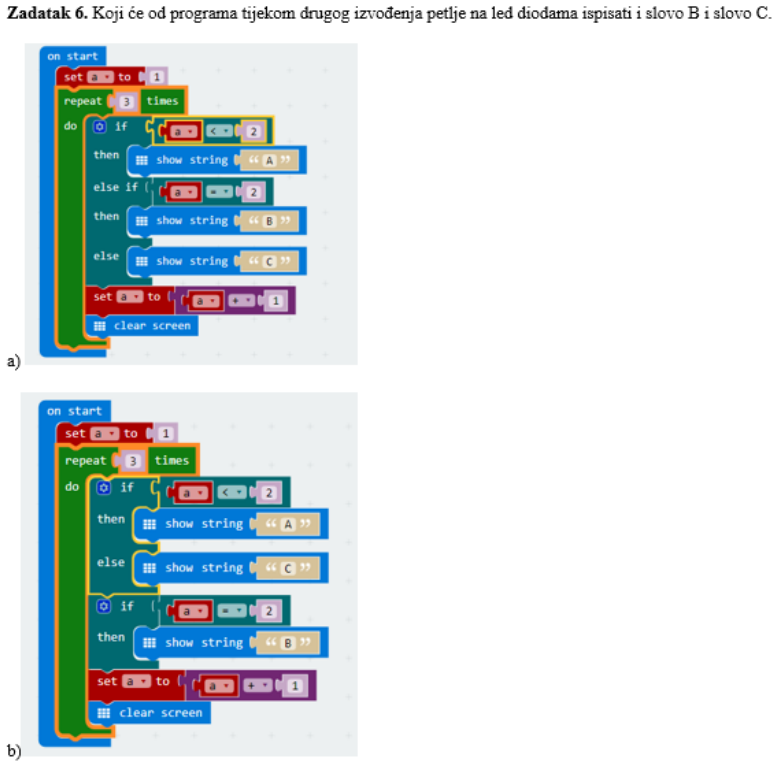

Slika 13. Šesti zadatak iz završnog testiranja 


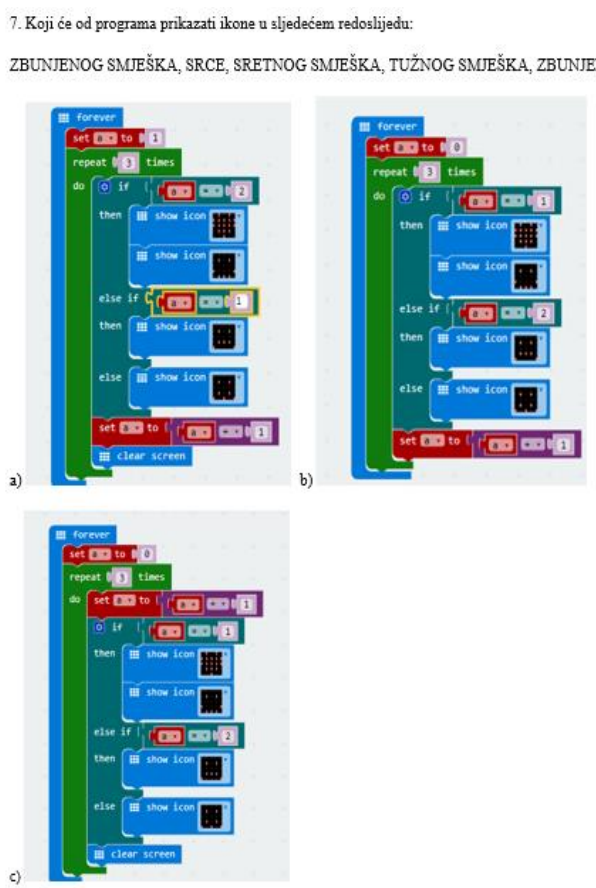

Slika 14. Sedmi zadatak iz završnog testiranja

Nakon što su učenici riješili završni test pristupili su anketi zadovoljstva. Anketa zadovoljstva je provjeravala kakav su učenicima ostavili dojam pojedini dijelovi ciklusa. Je li uvodno testiranje bilo teško ili jednostavno te koji im je zadatak bio najteži, a koji najzanimljiviji. Osim toga, koliko su im bili zanimljivi i shvatljivi zadaci s vježbi, a koliko projektni zadatak. Na kraju su još trebali iznijeti dojam o zadacima iz završnog testiranja te se izjasniti je li im Micro:bit dobar kao alat za učenje programiranja.

\section{Rezultati i analiza rezultata}

Uvodni i završni test su u kombinaciji s anketom donijeli rezultate koje na kraju treba analizirati. Prije analiziranja valja naglasiti da je prethodno realizaciji projekta i testiranja u školi, uvodni test dan kontrolnoj skupini učenika. Kontrolna skupina služila je da bi pokazala jesu li zadaci rješivi i u nekoj mjeri prikladni za učenike.

\subsection{Analiza uvodnog testa}

Uvodno testiranje je, baš kao što je prethodno napisano, provedeno na dvije različite skupine učenika. Sljedeći graf usporedno prikazuje riješenost zadataka za obje skupine (Slika 15.). Prije nego se analizira riješenost zadataka $s$ uvodnog testiranja važno je naglasiti da je kontrolnu skupinu činilo 6 učenika, dok je skupinu s učenicima iz osnovne škole činilo 13 učenika, što je dvostruko više. Unatoč tomu, možemo vidjeti da je većina zadataka podjednako riješena, pa možemo izabrati učenicima najteži i najlakši zadatak s uvodnog testiranja. Najlakši zadaci, koje su učenici kontrolne skupine riješili u potpunosti, su prvi i sedmi zadatak. Prije definiranja najtežeg zadatka može se primijetiti da su veća odstupanja u riješenosti zadataka vidljiva kod zadataka osam, devet, deset $\mathrm{i}$ jedanaest. To su zadaci s riječima koji su postavljeni u test $s$ razmišljanjem pa ih neće svi učenici znati riješiti. Najteži zadatak cijelog testiranja bio bi 10. zadatak tj. zadatak s Božićnim lampicama. Niti jedan od učenika iz kontrolne skupine nije riješio ovaj zadatak, a vidimo i da je jako mali broj učenika u drugoj skupini isti zadatak riješilo točno.

Slika 16. prikazuje graf riješenosti ulaznog

\section{RIJEŠENOST ZADATAKA UVODNOG} TESTA

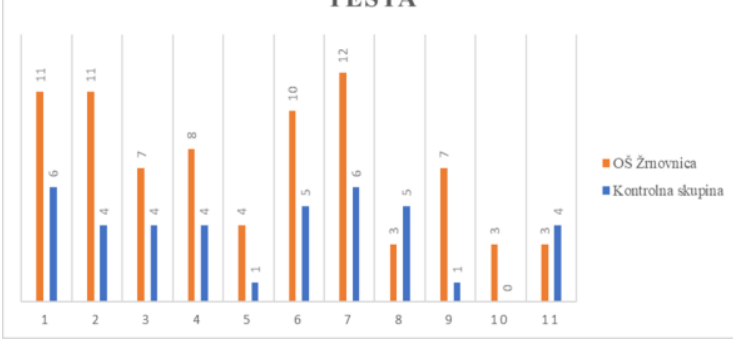

Slika 15.Usporedni graf riješenosti zadataka s uvodnog testiranja od strane kontrolne skupine i učenika iz Osnovne škole Žrnovnica

testa za svakog od učenika. Iz rezultata se vidi da je više od pola učenika riješilo više od 50 posto testa. Podaci su za potrebe izrade ovog grafa sortirani od najlošije riješenih testova pa sve do najbolje riješenog testa. 
Kao što se može vidjeti na grafu, za njegovu izradu korišteni su svi rezultati, znači i oni iz kontrolne skupine su pridodani prije sortiranja.

Nakon što smo vidjeli riješenost zadataka $s$ uvodnog testiranja možemo pogledati i koja rješenja su učenici odabrali umjesto ispravnih u tablici s Analizom distraktora uvodnih zadataka. $U$ tablici su odabrani zadaci s riječima (Tablica 2.).

POSTOTAK RIJEŠENOSTI ULAZNOG TESTA ZA SVAKOG UČENIKA

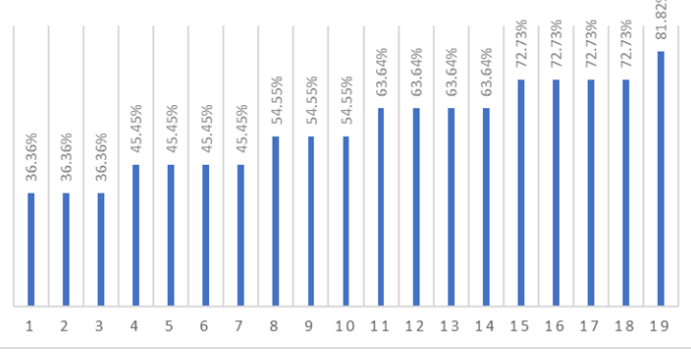

Slika 16. Graf riješenosti ulaznog testa za svakog učenika

Tablica 2. Analiza distraktora uvodnog testa

\begin{tabular}{|l|l|l|l|l|}
\hline 8 & & Neodgovoreno & $5 \%$ & 1 \\
\hline & a) & Netočan odgovor & $37 \%$ & 7 \\
\hline & b) & Točan odgovor & $42 \%$ & 8 \\
\hline & c) & Netočan odgovor & $15 \%$ & 3 \\
\hline 9 & & Neodgovoreno & $5 \%$ & 1 \\
\hline & a) & Netočan odgovor & $42 \%$ & 8 \\
\hline & b) & Netočan odgovor & $0 \%$ & \\
\hline & c) & Netočan odgovor & $0 \%$ & \\
\hline & d) & Netočan odgovor & $0 \%$ & \\
\hline & e) & Netočan odgovor & $10 \%$ & 2 \\
\hline & f) & Netočan odgovor & $0 \%$ & \\
\hline & g) & Netočan odgovor & $0 \%$ & \\
\hline & h) & Točan odgovor & $42 \%$ & 8 \\
\hline & i) & Netočan odgovor & $0 \%$ & \\
\hline 10 & & Neodgovoreno & $10 \%$ & 2 \\
\hline & a) & Točan odgovor & $15 \%$ & 3 \\
\hline & b) & Netočan odgovor & $26 \%$ & 5 \\
\hline & c) & Netočan odgovor & $10 \%$ & 2 \\
\hline & d) & Netočan odgovor & $37 \%$ & 7 \\
\hline 11 & & Neodgovoreno & $5 \%$ & 1 \\
\hline & a) & Netočan odgovor & $26 \%$ & 5 \\
\hline & b) & Točan odgovor & $37 \%$ & 7 \\
\hline & c) & Netočan odgovor & $10 \%$ & 2 \\
\hline & d) & Netočan odgovor & $21 \%$ & 4 \\
\hline
\end{tabular}

U osmom zadatku s vlakom i vagonima se može primijetiti učestalost pogrešnog odgovora pod a), što opasno konkurira točnom odgovoru pod b). Naime, u ovom zadatku se nezanemariv dio učenika izjasnio kako vlaku nedostaje 6 vagona, a točan odgovor je 7 . Taj podatak daje naznaku da zadatak možda nije dobro objašnjen. Moguće da je na slici dan mali broj vagona i da učenici iz tog razloga nisu mogli prepoznati uzorak. Druga opcija bi bila da su učenici prepoznali neki drugi uzorak, čije je postojanje pri kreiranju zadatka previđeno. Iz rješenja desetog zadatka, može se uočiti da je u rezultatima ukupni broj netočnog odgovora d) puno veći od ukupnog broja točnog odgovora a). Iz svega ovog može se zaključiti da su učenici vjerojatno ignorirali uvjet nakon kojeg lampice mijenjanju boju $u$ istoj minuti ili nisu poštivali redoslijed svijetljenja lampica pri rješavanju zadataka. Deveti zadatak je zanimljiv zato što se lutka pod a) razlikuje od točnog odgovora jedino po narukvici na drugoj ruci. Učenici su u ovom slučaju pri rješavanju zadatka zamijenili lutkinu desnu ruku za svoju desnu stranu.

\subsection{Analiza završnog testa}

Za analizu riješenosti zadataka završnog testa također je korištena analiza distraktora koja se nalazi u tablicama (Tablica 3. i 4.). U tablicama su odabrani samo zadaci koji su lošije riješeni.

Promotrimo li rezultate za zadatke u tablicama 3. i 4., možemo vidjeti da je riječ o zadacima u kojima su učenici u jednakom broju označili točan i netočan odgovor. Drugi zadatak je prvi u nizu takvih zadataka. Na njega je pet učenika dalo točan odgovor i uz to je pet učenika odabralo netočan odgovor c). Pogledamo li tekst zadatka, možemo zaključiti da su ti učenici vrlo vjerojatno površno pogledali zadatak, te nisu primijetili da je uvećavanje varijable smješteno unutar petlje od četiri ponavljanja. Druga opcija za objašnjenje je da učenici nisu shvatili koncept algoritma ponavljanja. Sljedeći kritično riješen zadatak je zadatak pod brojem 5 . U petom zadatku čak je šest učenika odabralo isti, pogrešan odgovor. 
Tablica 3. Analiza distraktora drugog zadatka završnog testa

\begin{tabular}{|l|l|l|l|l|}
\hline 2 & & Neodgovoreno & $0 \%$ & \\
\hline & a) & Netočan odgovor & $46 \%$ & 5 \\
\hline & b) & Netočan odgovor & $9 \%$ & 1 \\
\hline & c) & Točan odgovor & $46 \%$ & 5 \\
\hline & & & & \\
\hline & d) & Netočan odgovor & $0 \%$ & \\
\hline & & & & \\
\hline
\end{tabular}

Tablica 4. Analiza distraktora petog, šestog i sedmog zadatka završnog testa

\begin{tabular}{|l|l|l|l|l|}
\hline 5 & & Neodgovoreno & $0 \%$ & \\
\hline & a) & Netočan odgovor & $9 \%$ & 1 \\
\hline & b) & Netočan odgovor & $54 \%$ & 6 \\
\hline & c) & Točan odgovor & $36 \%$ & 4 \\
\hline & d) & Netočan odgovor & $0 \%$ & \\
\hline 6 & & Neodgovoreno & $0 \%$ & \\
\hline & a) & Netočan odgovor & $73 \%$ & 8 \\
\hline & b) & Točan odgovor & $27 \%$ & 3 \\
\hline 7 & & Neodgovoreno & $0 \%$ & \\
\hline & a) & Netočan odgovor & $0 \%$ & \\
\hline & b) & Točan odgovor & $46 \%$ & 5 \\
\hline & c) & Netočan odgovor & $54 \%$ & 6 \\
\hline
\end{tabular}

S obzirom na to da se u zadatku brojač u svakom izvršavanju petlje uvećava za tri, a ne za jedan, vrlo vjerojatno učenici taj bitni segment programa nisu primijetili. Stoga su zaokružili rješenje koje bi bilo točno da se varijabla u svakom izvršavanju petlje uvećala za jedan. Treći, a ujedno i najlošije riješen zadatak je zadatak pod brojem 6 . U šestom zadatku učenici su trebali prepoznati razliku između jednog grananja s više uvjeta i više grananja. Ovi rezultati pokazuju da učenici nisu usvojili ishod koji se odnosio na razlikovanje tih grananja. S obzirom na to da su učenici tijekom nastavnog procesa prošli samo jedan primjer ovakvog zadatka, te im isti nije koristio u izradi projekta, smatram da su učenici trebali proći više primjera sličnih ovom zadatku. Moguće je, da bi tek nakon nekoliko sličnih primjera, učenici $u$ potpunosti shvatili razliku između navedenih grananja te bi većina uspješnije riješila ovaj zadatak. Zadnji zadatak je također jedan od lošije riješenih zadataka. $U$ njemu su učenici trebali prepoznati koji će od ponuđenih programa dati ispravno prikazane slike na led diodama Micro:bita. Ovaj zadatak je zamišljen kao najteži zadatak testa, te je ovakav rezultat pretpostavljen.

Idući graf (Slika 17.) odnosi se na učeničku riješenost završnog testa koja je sortirana od najgoreg do najboljeg učenika. Može se primijetiti da je ukupna riješenost završnog testa gledajući po učenicima koji su pristupili testu znatno lošija, te da ima čak šest od jedanaest učenika koji su riješili lošije od pedeset posto.

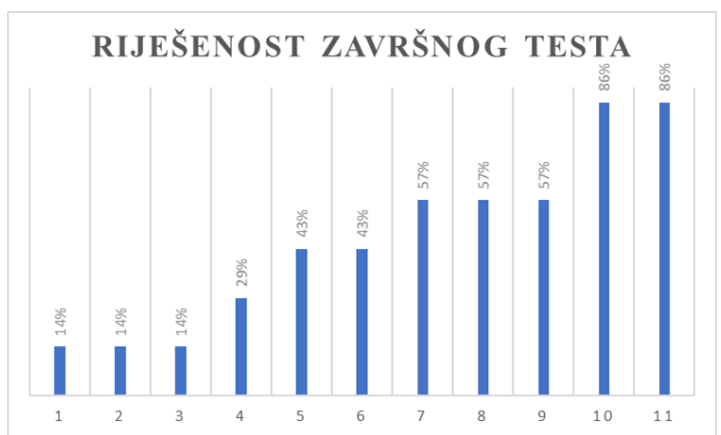

Slika 17.Graf riješenosti završnog testa za svakog od učenika koji je pristupio testu u postotcima

\subsection{Usporedna analiza uvodnog i završnog testa}

Sljedeći graf (Slika 18.) je usporedni prikaz ulaznog i završnog testa za svakog učenika koji je sudjelovao na jednom i drugom testiranju posebno. Rezultati su sortirani uzlazno po rezultatima završnog testiranja. Vidimo da je prvi učenik znatno lošije riješio završno testiranje, te da očito nije usvojio ishode koje je trebao, što je loše $\mathrm{s}$ obzirom na pokazane mogućnosti $\mathrm{u}$ uvodnom testiranju. Isto se može zaključiti i za drugog, trećeg, četvrtog, petog i šestog učenika, ali u ponešto manjoj mjeri jer je manji nesrazmjer između rezultata. Moguće je da bi rezultati bili sličniji u slučaju da je završnom testu dodan još koji zadatak iz istog područja. Rezultati koji variraju u razmaku od deset posto u razlici su očekivani rezultati koji pokazuju da su učenici s određenim mogućnostima iz logičkog, 
informatičkog razmišljanja usvojili gradivo ili barem dio gradiva. Najveće iznenađenje završnog testiranja je učenik koji je ulazni test riješio sa svega $36 \%$ točnosti, a završni s $86 \%$ Iz navedenog se može zaključiti da su učenici s $86 \%$ točnih odgovora jako dobro riješili test u odnosu na svoje kolege. Teško je reći jesu li i oni u potpunosti savladali gradivo jer bi bilo dobro da je završni test sadržavao još koji zadatak te da su učenici riješili preko $90 \%$ testa točno. Na grafu je prikazana linearna crta trenda. Vidimo da se dva učenika s približnim rezultatima iz ulaznog $i$ završnog testiranja nalaze najbliže liniji trenda te da su učenici s rezultatima bližima liniji ostvarili očekivane rezultate završnog testa s obzirom na riješenost uvodnog testa.

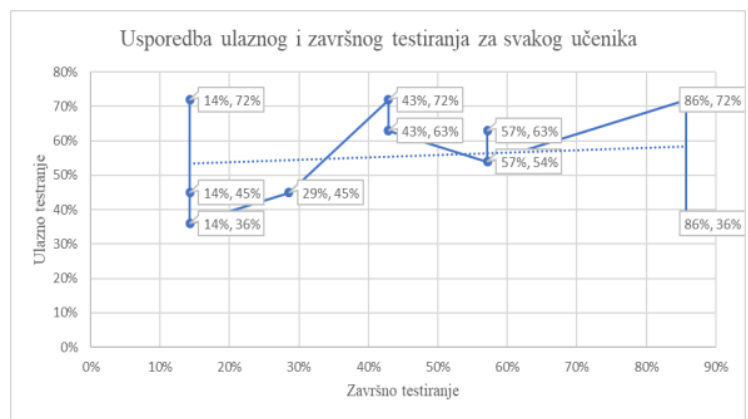

Slika 18. Graf usporednog prikaza ulaznog i završnog testa za svakog učenika u postotcima

Čimbenici koji su mogli utjecati na rezultate uvodnog, a ponajprije završnog testiranja:

- Blok sat informatike je u rasporedu smješten zadnja dva sata.

- Niti jedno od testiranja nije bilo za ocjenu.

- Učenici se nisu pripremali za test kod kuće.

- Manje učenika je rješavalo završni test.

Zadnji školski sati od učenika iziskuju poseban napor i koncentracija za rješavanje zadataka im je u drastičnom padu. S obzirom na to da je uvodno testiranje provedeno kao prvo u blok satu, a završno kao drugo, postoji mogućnost da je i to utjecalo na rezultate testiranja. Osim toga, niti jedno od testiranja se nije ocjenjivalo. Kad se neki test ne ocjenjuje, učenici nemaju dovoljnu motivaciju za posvećeno rješavanje zadataka. To bi značilo da su neke zadatke učenici možda pročitali i odgovorili površno, ne razmišljajući i bez dodatnog truda i raspisivanja uz zaključivanje. Treći razlog zbog kojeg su učenici mogli lošije riješiti test je taj što se kod kuće nisu pripremali za rješavanje testa jer test nije bio za ocjenu i nisu imali razloga. Još jedan od čimbenika koji je utjecao na cjelokupni dojam riješenosti zadataka je možda činjenica da troje učenika nije pristupilo završnom testiranju. Da su svi učenici koji su pristupili uvodnom testu rješavali i završni test, vjerojatno bi u konačnici dobili drugačije rezultate.

\subsection{Analiza ankete zadovoljstva}

Nakon što su analizirani rezultati uvodnog testiranja, napravljen je upitnik kako bi se analiziralo zadovoljstvo učenika (Slika 19.). Bodovna skala je postavljena tako da je broj 1 značio uopće se ne slažem, broj 2 ne slažem se, broj 3 niti se slažem, niti se ne slažem, broj 4 slažem se i za kraj broj 5 slažem se u potpunosti. Na mjesto pitanja dana je izjava:

- Zadaci iz uvodnog testiranja su mi bili razumljivi i nisu mi bili teški za riješiti.

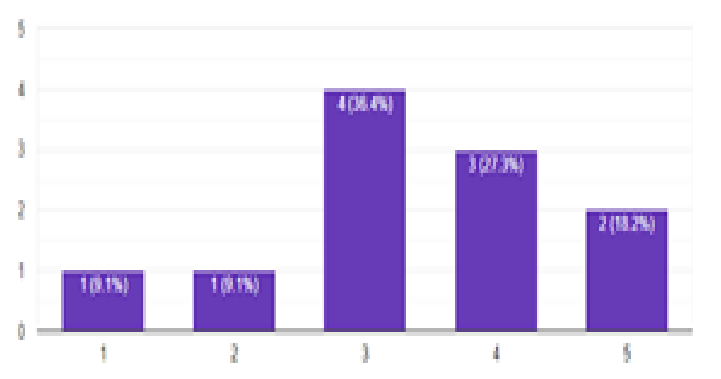

Slika 19. Graf iz ankete zadovoljstva : Zadaci iz uvodnog testiranja su mi bili razumljivi i nisu mi bili teški za riješiti

Dvoje učenika je izjavilo da je uvodno testiranje bilo teško, dok se čak pet učenika na neki način složilo s izjavom da uvodni zadaci nisu bili teški. Četiri od jedanaest učenika je ostalo suzdržano. Dva učenika su se u potpunosti složila s izjavom. Jedan od njih je ujedno i jedan od 
učenika koji je najbolje riješio uvodno testiranje, dok je drugi učenik ostvario osrednji rezultat. Vjerojatni razlog, zbog kojeg su učenici u većini ostali neutralni pri slaganju s izjavom, je nedovoljna definiranost same izjave. $U$ ovom slučaju jedna je izjava mogla biti podijeljena na dvije neovisne izjave. Nekim učenicima su zadaci možda bili razumljivi, ali ih svejedno nisu znali riješiti.

Sljedeći graf (Slika 20.) prikazuje nastavak na izjavu koji je učenicima bio najteži zadatak u uvodnom testu. A izjava je glasila:

- Najteži zadatak u uvodnom testiranju bio mi je..

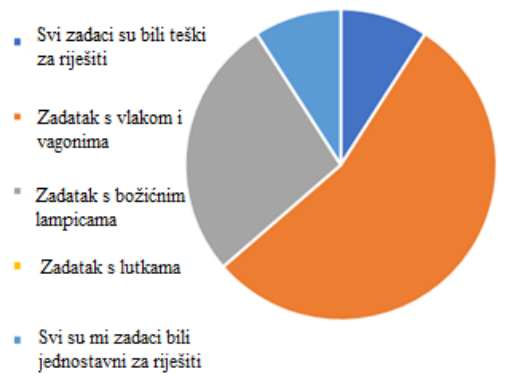

Slika 20. Graf iz ankete zadovoljstva: Odabir najtežeg zadatka uvodnog testiranja

Učenicima su ponuđene opcije bile zadaci $s$ riječima (od zadatka s vlakovima do zadatka $s$ božićnim lampicama), izjava da su im svi zadaci bili teški za riješiti, izjava da su im svi zadaci bili jednostavni za riješiti i opcija da sami izdvoje najteži zadatak. $U$ odgovorima se većina učenika izjasnila za zadatak s vlakom i vagonima kao najteži, zadatak s božićnim lampicama ide odmah nakon njega po izboru, dok je jedan od učenika odabrao opciju da su mu svi zadaci bili teški za riješiti, a drugi da mu niti jedan zadatak nije bio težak za riješiti. Zadatak s lutkama nitko od ispitanika nije označio kao najteži. Učenicima je bila ponuđena opcija da samostalno nadopune, ako im je neki drugi zadatak bio najteži, ali možda se nisu sjetili težeg zadatka, jer su te zadatke rješavali dva tjedna prije anketiranja. Stoga bi bilo bolje da su učenici odmah nakon uvodnog testiranja dobili prikladnu anketu u kojoj bi se jasno, bez prisjećanja, mogli izjasniti o najtežem zadatku. Osim toga, ovo anketno pitanje se moglo proširiti i u njega su se mogli pridodati svi zadaci iz uvodnog testiranja pa bi vrlo vjerojatno dobili i drugačije odgovore. Trenutno se mogu rangirati zadaci po anketnim odgovorima i zaključiti da su dva najteža zadatka po odabiru učenika:

1. Zadatak s vlakom i vagonima

2. Zadatak s božićnim lampicama

Treći graf (Slika 21.) prikazuje odgovor tj. nastavak na izjavu:

- Najzanimljiviji zadatak na uvodnom testiranju bio mi je...
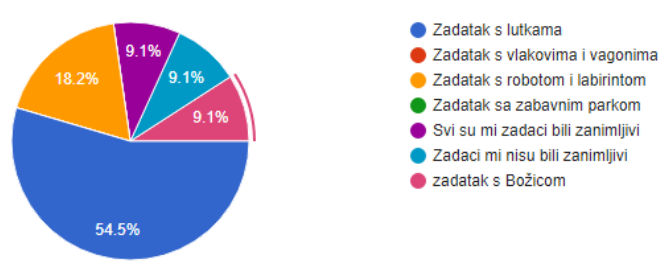

Slika 21. Graf iz ankete zadovoljstva : Najzanimljiviji zadatak iz uvodnog testiranja

Više od pola učenika je na tu izjavu nadopunilo da im je najzanimljiviji bio zadatak s lutkama, odmah nakon njega učenicima se svidio zadatak $s$ robotom i labirintom, jedan učenik je odgovorio da su mu svi zadaci bili zanimljivi, drugi da mu zadaci nisu bili zanimljivi i još je jedan učenik sam nadopunio kako mu je bio najzanimljiviji zadatak s Božićem tj. s Božićnim lampicama. Zanimljivo je da se niti jedan učenik nije odlučio za zadatak sa zabavnim parkom koji je bio jedan od najlakših zadataka u testu i kojeg je većina učenika riješila. Osim njega, nitko nije izabrao niti ponuđen zadatak s vagonima, koji je još u rezultatima prethodne izjave evidentno najteži zadatak po izboru učenika. Ovo anketno pitanje se također moglo izvesti tako da su se učenicima ponudili svi zadaci kao moguć odgovor. $U$ tom slučaju vjerojatno bi dobili drugačije zadatke jer se možda nakon dva tjedna učenici nisu mogli sjetiti svih zadataka iz ulaznog testa.

Četvrta izjava ankete odnosila se na nastavni proces i zadatke koje su učenici na njemu rješavali, tako da sljedeći graf (Slika 22.) pokazuje odgovor na izjavu: 
- Zadaci koje smo radili tijekom nastavnih sati

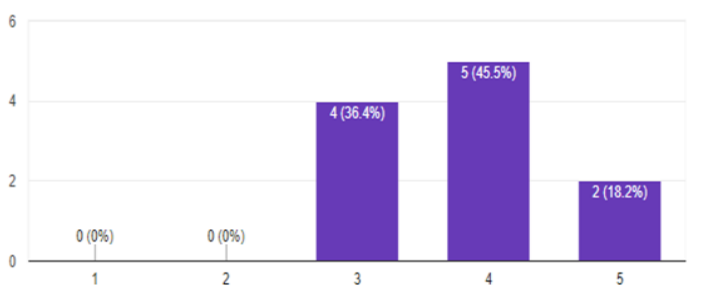

sam bez problema razumio/razumjela Slika 22.Graf iz ankete zadovoljstva: Razumijevanje odrađenih zadataka

Kao odgovor na ovu izjavu, većina učenika je odabrala pozitivan dio skale vrednovanja izjave. Sedam učenika se složilo, a neki i u potpunosti. Što znači da su zadaci obrađeni na vježbama bili razumljivi. Četiri učenika je ostalo neutralno. Iz čega možemo zaključiti da su svjesni da na satu nisu usvojili gradivo koje su trebali. Međutim, da je ova anketna izjava podijeljena na više izjava od kojih bi se svaka odnosila na jedno pitanje ili dio gradiva, sigurno bi dobili jasniju sliku i vjerojatno bi manje učenika ostalo neutralno. No vidimo da nema negativnih odgovora, prema tome možemo zaključiti da je rezultat zadovoljavajući.

Sljedeća anketna izjava odnosila se na zanimljivost zadataka koje su učenici prošli tijekom cijelog ciklusa pa je tvrdnja glasila:

- Zadaci koje smo radili tijekom nastave su mi bili zanimljivi

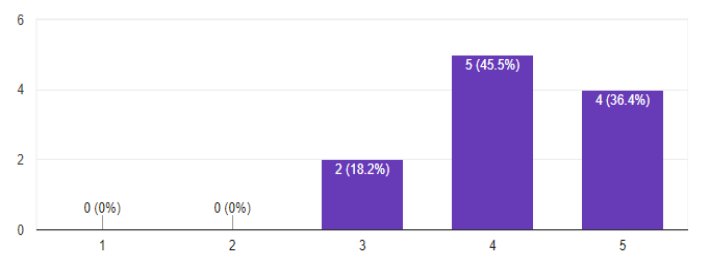

Slika 23.Graf iz ankete zadovoljstva : Zadaci koje smo radili tijekom nastave su mi bili zanimljivi

Učenici su u ovom slučaju uglavnom odgovorili na pozitivnoj tj. potvrdnoj strani ponuđenih odgovora (Slika 23.). Samo dva učenika su ostala suzdržana. Zanimljivo je da je jedan od dva učenika koja su ostala suzdržana osrednje riješio završni test, a drugi ga je znatno lošije riješio. Možda je njihov manjak motivacije uzrokovao lošije rezultate, no kako nije provedeno detaljno ispitivanje, ne možemo znati precizan odgovor. Detaljnije ispitivanje bi sigurno uključilo anketnu izjavu o zanimljivosti svakog zadatka pojedinačno. Ako bi $u$ ankete postavili detaljna pitanja o svakom zadatku posebno, imena zadataka i primjera bi morala biti prepoznatljiva i pamtljiva. Tako da bi u tom slučaju definitivno trebali izbjeći nazive kao što su Zadatak1, Primjer2 itd. Iz trenutnih rezultata za ovo anketno pitanje može se zaključiti da su učenicima zadaci uglavnom bili zanimljivi.

Napokon dolazimo do izjave koja se odnosi na projektni zadatak Šijavicu, tako da izjava glasi:

- Projektni zadatak Šijavica mi je bio zanimljiv..

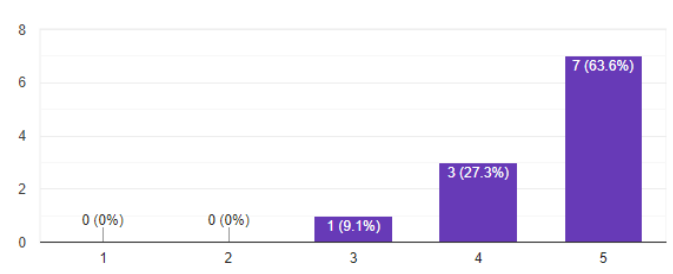

Slika 24. Graf iz ankete zadovoljstva: Projektni zadatak Šijavica mi je bio zanimljiv

Kao što se može vidjeti u rezultatima grafa (Slika 24.), na ovu izjavu je jako velik broj učenika odgovorio da se u potpunosti slažu. Od preostalih učenika su tri učenika ostala samo na slaganju s izjavom i jedan se učenik izjasnio kao suzdržan. Učenik koji je ostao neutralan, jedan je od onih koji su puno bolje riješili ulazno testiranje od završnog testa. Možda je i kod njega uzrok manjak motivacije tijekom zadnja dva blok sata, ali o tome ne možemo donositi dodatne zaključke jer nismo ustvrdili činjenice.

Slijedi anketna izjava postavljena učenicima:

- Projektni zadatak Šijavica sam u potpunosti shvatio/ shvatila 


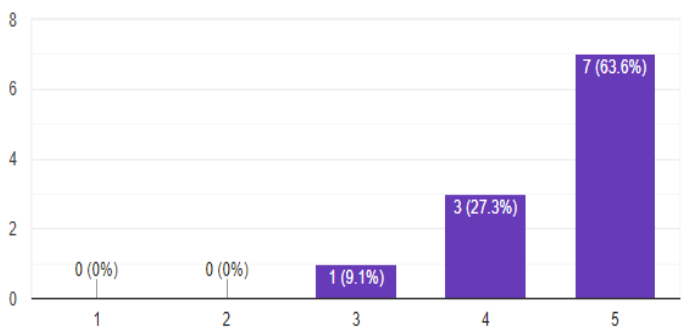

Slika 25.Graf iz ankete zadovoljstva: Projektni zadatak Šijavica sam u potpunosti shvatio/ shvatila

Pozitivno je da je velika većina učenika shvatila projektni zadatak u potpunosti (Slika 25.). Negativna strana je da učenici koji se nisu u potpunosti složili s njom, vjerojatno imaju neke nedoumice vezane za pojedine dijelove projektnog zadatka. Ova anketna izjava se mogla proširiti s pitanjem u kojem će učenici napisati par rečenica o tome što nisu shvatili pri izradi projektnog zadatka i tako jasno dati do znanja gdje je nastao problem.

Nakon par anketnih izjava koje su se bavile nastavnim djelom ciklusa, red je na izjavu vezanu za završno testiranje koja glasi:

- Zadaci iz završnog testiranja su mi bili razumljivi i nisu mi bili teški za riješiti.

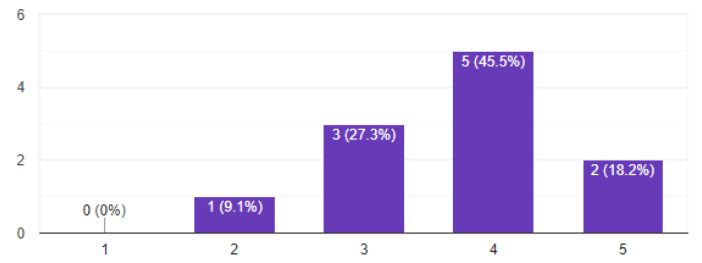

Slika 26.Graf iz ankete zadovoljstva: Zadaci iz završnog testiranja su mi bili razumljivi i nisu mi bili teški za riješiti.

Kao odgovor na ovu izjavu, većina je učenika označila da se slaže (ali ne u potpunosti), dva učenika se u potpunosti slažu s izjavom, tri su neutralna glasa, a jedan se učenik izjasnio kako su mu završni zadaci bili teški (postavio je odgovor na se ne slaže s izjavom). Slijedi i prikaz grafa (Slika 26.). Učenik koji je ostavio odgovor na negativnoj skali je među učenicima koji su osrednje riješili test, dok je većina dala pozitivne, pa nakon toga neutralne odgovore, iako riješenost završnog testa u globalu nije bila zadovoljavajuća. Ova anketna izjava mogla je biti razdvojena na dvije zasebne izjave. Tako bi dobili preciznije podatke i mogli bi vidjeti koliko učenika je shvatilo zadatke, a nije ih znalo riješiti, a koliko učenika je mislilo da je dobro shvatilo zadatke te da ih je dobro riješilo.

Deveta tvrdnja je postavljena učenicima s ciljem da malo razmisle i odgovore jesu li tijekom ciklusa naučili nešto novo i glasi:

- Tijekom ovog nastavnog ciklusa naučio/naučila sam nešto novo.

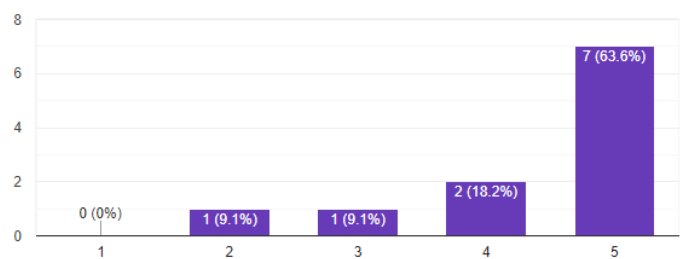

Slika 27.Graf iz ankete zadovoljstva: Tijekom ovog nastavnog ciklusa naučio/naučila sam nešto novo

Vidimo i ovdje jedan odgovor na negativnom dijelu skale (Slika 27.). Riječ je o učeniku koji nije prolazno riješio završno testiranje i možda mu cjelokupni pristup učenju u ovom slučaju ne odgovara. Pozitivno je da je većina učenika izjavila da je nešto novo naučila tijekom ovog nastavnog ciklusa. Negativna strana ove anketne izjave je ta što nije dobro definirana. Da bi dobili prave povratne informacije $u$ kombinaciji $s$ ovom izjavom učenici bi u kratkim crtama trebali napisati što su novog naučili kroz održanu projektnu nastavu.

I dolazimo do zadnjeg, ali ne manje važnog grafa (Slika 28.) koji prikazuje odgovor učenika na tvrdnju:

- Micro:bit je dobar alat za učenje programiranja

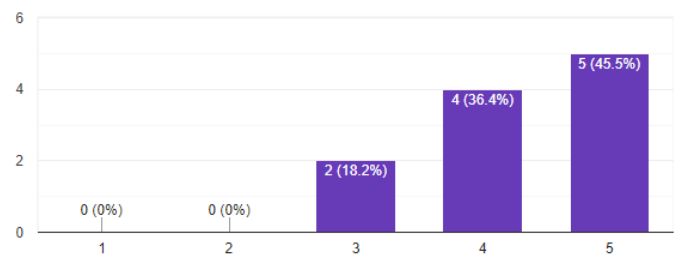

Slika 28. Graf iz ankete zadovoljstva: Micro:bit je dobar alat za učenje programiranja 
Kao odgovor na ovu tvrdnju vidljivo je da je velika većina učenika iskazala slaganje $s$ tvrdnjom, od čega se veći broj odgovora odnosio na potpuno slaganje. Dvoje učenika ostalo je neutralno, ali, gledajući u cjelini, konačni rezultati opravdavaju Micro:bit kao jedan od alata s kojima se početnicima programiranje može predstaviti na jednostavan i zanimljiv način.

\subsection{Zaključna analiza}

Ako pogledamo cjelokupnu sliku rezultata, može se vidjeti da je uvodno testiranje riješeno u očekivanom omjeru. Većina učenika dobila je srednje rezultate, dok je manji broj učenika lošije i bolje riješio test. Tijekom samog održavanja projektnih zadataka učenici su pokazali zainteresiranost i motiviranost. Ostavili su dojam da su im se svidjeli zadaci, a ponajviše projektni zadatak Šijavica. Iz prethodne ankete vidi se i da učenici u velikoj većini doživljavaju Micro:bit zanimljivim i atraktivnim za učenje programiranja te da većina učenika smatra da je tijekom cijelog nastavnog ciklusa ipak nešto naučila. Zanimljivo je i da se većina učenika izjasnila kako su im završni zadaci bili jednostavni za riješiti. Taj podatak dovodi do pitanja koliko su učenici zapravo usvojili gradivo, no uz rezultate možemo uzeti u obzir čimbenike kao što su održavanje završnog testiranja zadnji školski sat i moguć nedostatak motivacije za rješavanje testa jer test $u$ niti jednom trenu za učenika neće rezultirati ocjenom. Osim toga, valja naglasiti da ni sama anketa nije bila dovoljno precizna, te da su neka anketna pitanja i izjave mogli biti bolje definirani. Preciznije definirana pitanja mogla su rezultirati boljim povratnim informacijama iz kojih se moglo saznati koji zadaci sa sata su bili zanimljivi, koji neshvatljivi te što su novo učenici naučili itd.

\subsection{Prijedlozi za poboljšanje}

Nakon zaključaka proizašlih iz analize testiranja i ankete možemo vidjeti da se učenicima način savladavanja nastavnog sadržaja kroz izradu parcijalnih projektnih zadataka sviđa te da im je drugačiji i zanimljiviji. Nadalje, možemo zaključiti da djeluje motivirajuće na učenike. No ipak za bolje rezultate mogle bi se uvesti navedene promjene:

- Angažirati učenika i za rad kod kuće,

- U nastavni ciklus dodati više vježbi,

- Detaljnije razraditi anketu zadovoljstva.

Prvi prijedlog se odnosi na veći angažman i samostalan rad učenika izvan nastave. Pri tom se ne traži od učenika da uče za završni test, već im se stvaraju tzv. istraživačke potrebe. Drugim riječima, moguće je prirediti odgovarajuća istraživačka pitanja i izazove koji će učenika potaknuti na razmišljanje $\mathrm{i}$ dodatne aktivnosti. Takve aktivnosti mogu činiti mala istraživanja koja učenici trebaju provoditi u paru ili grupi. Bitno je samo učenicima u takvim situacijama naglasiti važnost tog rada, tako da ga sigurno obave prije idućeg školskog sata, odnosno, ciklusa.

Nastavni ciklus s više vježbi je drugi prijedlog. U takvom obliku nastavnik bi mogao proći više primjera za svaki pojam i koncept, te bi učenici imali priliku bolje shvatiti i usvojiti gradivo. Osim toga, sam projektni zadatak bi se mogao razvući na znatno više školskih sati i tako se približiti „pravoj“ projektnoj nastavi. U tom slučaju bi se tek $\mathrm{u}$ idućem tjednu moglo napraviti završno testiranje. Problem koji bi mogao izazvati ovaj prijedlog je manjak satnice i količina gradiva koju nastavnik treba obraditi.

Zadnji prijedlog je da se anketa zadovoljstva ubaci na kraju svakog blok-sata i da izjave u anketi budu preciznije definirane te da se svaki tjedan napravi analiza rezultata ankete. Tako bi na kraju svakog blok-sata nastavnik od učenika dobio informacije zahvaljujući kojima bi tijekom idućih sati mogao uvesti neke promjene. Primjerice, ako je nastavnik iz ankete uočio da većina učenika nije shvatila jedan dio gradiva, može ga ponovno objasniti na nekom drugom primjeru.

\section{Zaključak}

Nakon predloženog sustava za planiranje učenja nastavnih sadržaja kroz osmišljavanje projektnih zadataka te njihove razrade i primjene u praksi, dobili smo određene povratne informacije preko završnog testiranja $\mathrm{i}$ ankete zadovoljstva. Dok završno testiranje daje naznake lošije riješenosti 
koja ne ide u prilog predloženom sustavu za planiranje učenja i poučavanja putem izoliranih projektnih zadataka, anketa zadovoljstva govori drugačije. Učenicima se uglavnom svidio ovakav pristup, smatraju i da je Micro:bit dobar alat za poučavanje programiranja. Kako je jedan od ishoda nastavnog sata u kojem su učenici realizirali projektni zadatak bio baš razviti kreativnost i stvaralački duh, možemo reći da je ishod ispunjen jer su učenici putem svojih odgovora pokazali motivaciju i zainteresiranost.

$\mathrm{Na}$ kraju analize rezultata dani su i neki prijedlozi za poboljšanje same realizacije, te samog sustava. Jedan od prijedloga za poboljšanje odnosi se na stvaranje istraživačkih potreba učenika tijekom čega bi se učenici fokusirali na sadržaje i izvan nastave. Ovakvo poboljšanje bi vjerojatno polučilo drugačije rezultate testiranja. Na kraju možemo samo zaključiti da su učenici projektni zadatak uspješno odradili $i$ većinski se izjasnili da su ga u potpunosti shvatili te da im je bio zanimljiv. Iz toga vidimo da se učenicima sviđa ovakav rad te da bi rado sudjelovali u projektnoj nastavi koja bi trebala slijediti nakon ovakvih zadataka. Razlog tome je što upravo na ovaj način učenici dobivaju na važnosti u kreiranju nastavnog procesa. Uz to je nezanemariva važnost njihova angažmana, aktivnosti i stjecanja suradničkih vještina neophodnih za razvoj sposobnosti potrebnih za učenje temeljeno na projektima.

U konačnici, predloženi sustav zamišljen je tek kao priprema učenika za složeniju, projektnu nastavu i učenje, čija razrada nije predmetom ovog rada, ali će zasigurno postati strategija bez prave alternative $u$ operacionalizaciji kurikulumu nastave informatike.

\section{Literatura}

Brankica, Z. (2014). Utjecaj projektne nastave na promjenu stava kod učenika prema nastavnim sadržajima iz biologije. Educatio Biologiae, (2014), 18-26.

Čižmešija, A. (2006). Projektna nastava matematike. Seminar $\mathrm{Za}$ Nastavnike Matematike Republike Hrvatske-Srednja Škola.
Curto, B., Moreno, V. (2016). Robotics in Education. Journal of Intelligent \& Robotic Systems, 81(1), 3-4.

dos Santos, E. F., Gonçalves, B. C. M., de Oliveira, K. B., Silva, M. B. (2018). Project Based Learning Applied to Technical Drawing. Creative Education, 09(03), 479-496.

Elkin, M., Sullivan, A., Umashi Bers, M. (2014). Implementing a Robotics Curriculum in an Early Childhood Montessori Classroom. Journal of Information Technology Education: Innovations in Practice, 13, 153169.

Forte, A., Guzdial, M. (2005). Motivation and nonmajors in computer science: Identifying discrete audiences for introductory courses. IEEE Transactions on Education, 48(2), 248253.

Jurčić, M. (2010). Nastavni kurikulum kao poticaj razvoju socijalnih kompetencija učenika. Pedagogijska Istraživanja, 7(2), 205-215.

Mirković, M. (2015). Nastavne metode u informatici / računalstvu. Tehnička škola Požega

Mubin, O., Stevens, C. J., Shahid, S., Mahmud, A. Al, Dong, J.-J. (2013). a Review of the Applicability of Robots in Education. Technology for Education and Learning, 1(1).

Pearlman, B., Thomas, J. W. (2000). A review of research on project-based learning. $A n$ Rafael, CA: Autodesk Foundation.,

Šuliček, D. (2011). Povezanost standardne $i$ projektne nastave - projektno orijentirana nastava u informatici

Uludag, S., Karakus, M., Turner, S. W. (2011). Implementing ITO/CSO with scratch, app inventor for android, and lego mindstorms. SIGITE'11 - Proceedings of the 2011 ACM 


$$
\begin{aligned}
& \text { Special Interest Group for Information } \\
& \text { Technology Education } \\
& \text { (October), 183-189. }
\end{aligned}
$$

Visković, I. (2016). Projektna nastava kao područje unaprjeđenja kvalitete škole. Školski Vjesnik: Časopis Za Pedagogijsku Teoriju I Praksu, 65(Tematski broj), 381-391.

Zainal, N. F. A., Shahrani, S., Yatim, N. F. M., Rahman, R. A., Rahmat, M., Latih, R. (2012). Students' Perception and Motivation Towards Programming. Procedia - Social and Behavioral Sciences, 59, 277-286.

\title{
System for planning and implementation of project tasks in computer science teaching
}

\begin{abstract}
Project-based learning and teaching is a qualitative departure from classical learning, and it is different and more interesting for pupils. This paper presents a proposal for a simple system for planning teaching Computer science oriented to solving project tasks, as a proposal for teachers to prepare pupils for more complex project-based learning. Such a system enables planning, defining the goal, outcomes, initial testing, realization, verification of results and satisfaction analysis. The aim of this approach is to bring pupils through an interesting topic (mini-project) to curriculum issues and, based on student feedback, identify their motivation for more complex strategies, such as project-based learning.
\end{abstract}

Keywords: Micro:bit, programming, project-based teaching, project task. 